Jurnal Bidan Cerdas
e-ISSN: 2654-9352 dan p-ISSN: 2715-9965
Volume 3 Nomor 2, 2021
DOI: 10.33860/jbc.v3i2.420
Website: http://jurnal.poltekkespalu.ac.id/JBC
Penerbit: Poltakk Kemenkes Palu

\title{
Gambaran Tingkat Kecemasan dan Kadar Hormon Kortisol Ibu Nifas
}

\author{
Ni Putu Dian Ayu Anggraeni $\square$, Baiq Eka Putri Saudia \\ Poltekkes Kemenkes Mataram \\ 凹Email Korespondensi: niputudianayu@gmail.com
}

\section{ARTICLE INFO \\ Article History: \\ Received: 2021-04-28 \\ Accepted: 2021-05-30 \\ Published: 2021-06-12}

\section{Kata Kunci: \\ Kecemasan; Kadar Kortisol; lbu Nifas}

\author{
Keywords: \\ Anxiety; \\ Cortisol levels; \\ Postpartum.
}

\begin{abstract}
ABSTRAK
Pendahuluan: Pada hari-hari pertama periode masa nifas seringkali terjadi masalah baik fisik, social, emosional, dan psikis. Sejumlah bukti menunjukkan bahwa gejala depresi postpartum berkaitan dengan peningkatan kadar kortisol. Kadar kortisol yang lebih buruk diakibatkan karena stres psikologis pasca melahirkan. Tujuan: Menganalisis gambaran tingkat kecemasan dan kadar hormon kortisol ibu nifas. Metode: penelitian ini menggunakan Survei Analitik dengan pendekatan Cross Sectional. Jumlah sampel 38 sampel yang memenuhi kriteria inklusi dengan sampel simple random sampling. Pengumpulan data menggunakan kuesioner PSAS untuk kecemasan dan pemeriksaan ELISA untuk kadar hormon kortisol. Analisa data menggunakan analisis univariate dan uji korelasi pearson. Hasil: Dari 38 responden, sebagian besar ibu nifas di 24 jam pertama pasca melahirkan mengalami kecemasan sedang $47,4 \%$ dengan ratarata kadar hormon kortisol $10,034 \mathrm{ng} / \mathrm{ml}$. Rata-rata kadar hormon kortisol ibu nifas primipara 14,60ng/ml lebih tinggi dibandingkan multipara yaitu 7,42ng/dl. Kesimpulan: Terdapat perbedaan signifikan kadar hormon kortisol ibu nifas primipara dan multipara dengan nilai $p=0,017$. Ada hubungan signifikan antara skor kecemasan dengan kadar hormon kortisol dengan nilai $p<0,001$. Penelitian selanjutnya diperlukan upaya-upaya penurunan kecemasan pada ibu nifas.
\end{abstract}

\begin{abstract}
Introduction: Physical, social, mental, and psychological issues are common in the first few days after giving birth. According to some research, postpartum depression symptoms are linked to high cortisol levels. Postpartum psychological stress causes higher cortisol levels. Objective: The aim of this study was to look at postpartum mother's anxiety and cortisol levels. Methods: An Analytical Survey with a Cross Sectional Approach is used in this analysis. With simple random sampling, there were 38 samples that met the inclusion criteria. Data was collected using the PSAS questionnaire for anxiety and an ELISA test for cortisol levels. Univariate and pearson correlation test is used in the data analysis. Results: The majority of postpartum mothers reported mild anxiety in the first 24 hours after childbirth, with an average cortisol level of $10.034 \mathrm{ng} / \mathrm{ml} 47.4 \%$. The average level of the puerperal hormone cortisol in primiparous women was $14.60 \mathrm{ng} / \mathrm{ml}$ higher than in multiparous women $7.42 \mathrm{ng} / \mathrm{dl}$. Conclusion: With a p value of 0.017 , there was a substantial difference in cortisol levels between primiparous and multiparous postpartum mothers. With a $p$ value $<0.001$, there was a close connection between anxiety score and cortisol levels. Future studies would need to focus on making it easier for postpartum mothers to feel less anxious.
\end{abstract}




\section{PENDAHULUAN}

Masa nifas dimulai setelah persalinan dan berlangsung selama sekitar enam hingga delapan minggu (Ahmadi et al., 2014; Martínez-Galiano, Hernández-Martínez, Rodríguez-Almagro, Delgado-Rodríguez, Rubio-Alvarez, et al., 2019). Pada hari-hari pertama periode ini seringkali terjadi masalah baik fisik, social, emosional, dan psikis. Masalah ini dapat berlangsung selama enam minggu hingga satu tahun setelah melahirkan (Martínez-Galiano, Hernández-Martínez, Rodríguez-Almagro, DelgadoRodríguez, \& Gómez-Salgado, 2019). Gejala yang sering ditemukan pada jam-jam pertama pasca melahirkan diantaranya kelelahan, nyeri, gelisah, serta kekhawatiran ibu atas peran barunya sebagai ibu (Anggraeni et al., 2020; Wahyuningsih, 2018).

Beberapa ibu nifas akan mengalami gangguan psikologis akibat dari perubahan hormon pasca melahirkan. Faktor psikologi berhubungan dengan kecemasan dan meningkat pada kejadian depresi postpartum (Ross \& McLean, 2006; Wenzel \& Stuart, 2011). Tingkat prevalensi kecemasan postpartum berkisar dari 0,5\% hingga 2,9\% dimana pada periode awal pasca persalinan ditemukan tingkat gangguan kecemasan sosial berkisar dari 0,2\% hingga 6,5\% (Wenzel \& Stuart, 2011). Wanita dalam menghadapi aktifitas dan peran barunya sebagai ibu membutuhkan beberapa penyesuaian. Sebagian wanita berhasil menyesuaikan diri dengan baik, namun beberapa wanita tidak berhasil menyesuaikan diri bahkan mengalami gangguan-gangguan psikologi mulai dari baby blues, depresi postpartum, dan bila tidak terdeteksi dan diatasi sejak awal dapat berakibat lebih buruk menjadi psikosa postpartum (Marmi, 2011; Zagoto, 2020). Dampak dari ibu dengan depresi postpartum menyebabkan berkurangnya ketertarikan pada bayinya. Para ibu juga kurang dapat merawat bayinya secara maksimal dan kurang antusias dalam menyusui, sehingga kebersihan, kesehatan dan perkembangan bayinya juga kurang optimal (Machmudah, 2015)

Data WHO, 2016 menunjukkan wanita di negara maju hingga 20\% mengalami gangguan masalah kesehatan mental pasca melahirkan (Fallon et al., 2016; WHO, 2016). Sedangkan kejadian depresi postpartum secara global diperkirakan terjadi 100-150 per 1000 kelahiran hidup. Sementara psikosa postpartum memiliki prevalensi 0,89 hingga 2,6 per 1000 kelahiran. Beberapa penelitian sudah dilakukan dan difokuskan pada depresi postpartum, sementara gejala kecemasan sebagian besar diabaikan. Namun, kecemasan pascapartum telah menjadi kondisi yang menarik bagi peneliti dan praktisi perinatal karena tingginya tingkat prevalensi dan dampaknya pada ibu dan bayi (Fallon et al., 2016; Paul et al., 2013).

Berdasarkan studi pendahuluan di Puskesmas Srondol Kota Semarang melalui wawancara dengan 4 ibu postpartum, 3 diantaranya ibu primipara mengalami kecemasan sejak mendekati proses persalinan hingga kelahiran bayinya. Untuk puskesmas sendiri belum memiliki prosedur tetap dalam hal skrining psikologi. Sejumlah bukti menunjukkan bahwa gejala depresi postpartum berkaitan dengan peningkatan kadar kortisol basal (Gaynes et al., 2005), peningkatan respons kortisol mempengaruhi proses pemulihan tubuh (Bhagwagar et al., 2005), dan ditemukan pemulihan tubuh dengan kadar kortisol yang lebih buruk diakibatkan karena stres psikologis pasca melahirkan (Field et al., 2013). Penelitian ini yang betujuan untuk menganalisis gambaran tingkat kecemasan dan kadar hormon kortisol ibu nifas.

\section{METODE PENELITIAN}

Metode penelitian ini menggunakan survei analitik dengan pendekatan CrossSectional. Populasi pada penelitian ini adalah semua ibu nifas normal pada bulan 
Februari sampai dengan April 2019 di 3 puskesmas dan 1 praktik mandiri bidan di Kota Semarang. Penentuan jumlah sampel menggunakan rumus Lemeshow dan diperoleh 38 responden yang memenuhi kriteria inklusi yaitu ibu nifas dengan riwayat persalinan normal dengan teknik pengambilan sampel simple random sampling. Pengumpulan data pada penelitian ini dengan mengumpulkan data primer yang sesuai dengan variabel independen skor kecemasan dan variabel dependen kadar hormon kortisol melalui pembagian kuesioner terkait karakteristik responden dan lembar kuesioner kecemasan PSAS (postpartum specific anxiety scale) yang terdiri dari 51 pertanyaan dengan rentang skor 51-204 dengan cut poin 112 (depresi). Untuk kriteria tingkat kecemasan diperoleh bila cemas ringan; skor 51-70, cemas sedang: skor 71-90, cemas berat; skor 91-111, dan gangguan panik/depresi: skor >112 (Anggraeni et al., 2019; Fallon et al., 2016), serta dilakukan Pemeriksaan kadar hormon kortisol saliva dengan teknik ELISA. Pengambilan saliva ibu pada 24 jam pertama masa nifas dengan kadar hormon kortisol normal: 5-21,6 ng/ml.

Penelitian ini telah dinyatakan layak etik oleh Komisi Etik Fakultas Kedokteran Gigi Universitas Islam Sultan Agung Semarang nomor 061/B.1-KEPK/SA$\mathrm{FKG/IV/2019}$. Analisis data menggunakan program software SPSS 22.0. Analisis data dalam penelitian ini menggunakan analisis univariate dan uji korelasi pearson.

\section{HASIL PENELITIAN}

Berdasarkan penelitian yang telah dilakukan, maka diperoleh hasil penelitian sebagai berikut:

Tabel 1. Distribusi Frekuensi Karakteristik Responden Berdasarkan Usia, Paritas, Pendidikan, Kecemasan, dan Kadar Hormon Kartisol

\begin{tabular}{lcc}
\hline Karakteristik Responden & Frekuensi & Persentase (\%) \\
\hline Usia lbu & 10 & 26,3 \\
$20-25$ & 18 & 47,4 \\
$26-30$ & 10 & 26,3 \\
$31-35$ & & \\
Paritas & 13 & 34,2 \\
Primigravida & 25 & 65,8 \\
Multigravida & & 21,1 \\
Pendidikan & 8 & 15,8 \\
SD & 6 & 44,7 \\
SMP & 17 & 18,4 \\
SMA & 7 & 42,1 \\
Perguruan Tinggi & 16 & 47,4 \\
Tingkat Kecemasan & 18 & 10,5 \\
Cemas ringan & 5 & \\
Cemas sedang & & \\
Cemas berat & & \\
Skor Kecemasan & $5,184 \pm 13,962$ & \\
Mean $\pm S D$ & 54 & \\
Min & 111 & \\
Max & $10,034 \pm 8,699$ & \\
Kadar Hormon Kortisol & 2,7 & \\
Mean $\pm S D$ & 54,0 & \\
Min & & \\
Max & & \\
\hline Sumber: Data Primer, 2019 & &
\end{tabular}


Berdasarkan tabel 1. menunjukkan bahwa karakteristik responden berdasarkan usia paling banyak berusia 26-30 tahun yaitu 47,4\%. Karakteristik responden berdasarkan paritas sebagian besar multipara $65,8 \%$ dan $34,2 \%$ primipara. Untuk tingkat pendidikan responden sebagian besar berpendidikan SMA 44,7\%, berpendidikan SD 21,1\%, berpendidikan SMP 15,8 \% dan berpendidikan perguruan tinggi $18,4 \%$.

Distribusi frekuensi responden berdasarkan kecemasan ditinjau dari skor kuesioner PSAS (Postpartum Spesific Anxiety Scale) diperoleh hasil responden mengalami kecemasan sedang 47,4\%, kecemasan ringan $42,1 \%$ dan terdapat $10,5 \%$ mengalami kecemasan berat dengan rata-rata skor kecemasan 79,184 dengan skor tertinggi 111 dan skor terendah 54. Distribusi frekuensi responden berdasarkan kadar hormon kortisol diperoleh hasil rata-rata kadar hormon kortisol responden adalah $10,034 \mathrm{ng} / \mathrm{dl}$ dengan kadar tertinggi $54,0 \mathrm{ng} / \mathrm{ml}$ dan terendah $2,7 \mathrm{ng} / \mathrm{ml}$.

Tabel 2. Distribusi Frekuensi Usia Ibu, Paritas, Pendidikan Berdasarkan Tingkat Kecemasan

\begin{tabular}{|c|c|c|c|c|c|c|c|c|c|}
\hline \multirow{3}{*}{ Variabel } & \multicolumn{6}{|c|}{ Tingkat Kecemasan } & & & \multirow{3}{*}{ Nilai $p$} \\
\hline & \multicolumn{2}{|c|}{$\begin{array}{l}\text { Cemas } \\
\text { Ringan }\end{array}$} & \multicolumn{2}{|c|}{$\begin{array}{l}\text { Cemas } \\
\text { sedang }\end{array}$} & \multicolumn{2}{|c|}{$\begin{array}{c}\text { Cemas } \\
\text { berat }\end{array}$} & \multicolumn{2}{|c|}{ Jumlah } & \\
\hline & $\mathbf{n}$ & $\%$ & $\mathbf{n}$ & $\%$ & $\mathbf{n}$ & $\%$ & $\mathbf{n}$ & $\%$ & \\
\hline \multicolumn{9}{|l|}{ Usia Ibu } & \multirow{4}{*}{$0,015^{\star}$} \\
\hline $20-25$ & 0 & 0,0 & 9 & 90,0 & 1 & 10,0 & 10 & 100 & \\
\hline $26-30$ & 11 & 61,1 & 6 & 33,3 & 1 & 5,6 & 18 & 100 & \\
\hline $30-35$ & 5 & 50,0 & 3 & 30,0 & 2 & 20,0 & 10 & 100 & \\
\hline \multicolumn{10}{|l|}{ Paritas } \\
\hline Primipara & 2 & 15,4 & 8 & 61,5 & 3 & 23,1 & 13 & 100 & \multirow{2}{*}{$0,028^{*}$} \\
\hline Multipara & 14 & 56,0 & 10 & 40,0 & 1 & 4,0 & 25 & 100 & \\
\hline \multicolumn{10}{|l|}{ Pendidikan } \\
\hline SD & 3 & 37,5 & 3 & 37,5 & 2 & 25,9 & 8 & 100 & \multirow{4}{*}{0,750} \\
\hline SMP & 2 & 33,3 & 3 & 50,0 & 1 & 16,7 & 6 & 100 & \\
\hline SMA & 8 & 47,1 & 8 & 47,1 & 1 & 5,9 & 17 & 100 & \\
\hline PT & 3 & 42,9 & 4 & 57,1 & 0 & 0,0 & 7 & 100 & \\
\hline
\end{tabular}

Chi-square

*Level significance $<0,05$

Berdasarkan tabel 2. diperoleh hasil kecemasan berat lebih banyak $20 \%$ terjadi pada ibu yang berusia 30-35 tahun, sedangkan kecemasan ringan paling banyak terjadi pada responden yang berusia $26-30$ tahun yaitu $61,1 \%$. Terdapat hubungan signifikan antara usia ibu dengan tingkat kecemasan dengan nilai $p=0,015$. Untuk paritas diperoleh hasil kecemasan berat paling banyak terjadi pada primipara yaitu $23,1 \%$ dan kecemasan ringan sebagian besar terjadi pada multipara yaitu $56,0 \%$. Terdapat hubungan signifikan antara paritas dengan tingkat kecemasan dengan nilai $p=0,028$. Sedangkan, untuk tingkat pendidikan, kecemasan berat paling banyak terjadi pada responden dengan tingkat pendidikan SD yaitu $25,9 \%$, kecemasan ringan $47,1 \%$ terjadi pada responden dengan pendidikan SMA, dan kecemasan sedang $47,1 \%$ terjadi pada responden dengan pendidikan SMA. Tidak terdapat hubungan signifikan antara tingkat pendidikan dengan tingkat kecemasan dengan nilai $p=0,750$. 
Tabel 3. Distribusi Frekuensi Kadar Hormon Kortisol lbu Berdasarkan Paritas

\begin{tabular}{ccccc}
\hline & Paritas & $\mathbf{n}$ & Mean \pm SD & Nilai $\boldsymbol{p}$ \\
\hline $\begin{array}{c}\text { Kadar } \\
\text { Hormon } \\
\text { Kortisol }\end{array}$ & Primipara & 13 & $14,60 \pm 12,51$ & \multirow{2}{*}{0,017} \\
\cline { 2 - 4 } & Multipara & 25 & $7,65 \pm 4,59$ & \\
\hline
\end{tabular}

${ }^{*}$ Level significance $<0,05$

Berdasarkan tabel 4. diperoleh hasil rata-rata kadar hormon kortisol pada primipara yaitu $14,60 \mathrm{ng} / \mathrm{ml}$ lebih tinggi dibandingkan multipara yaitu 7,42 $\mathrm{ng} / \mathrm{dl}$. Terdapat perbedaan signifikan kadar hormon kortisol pada primipara dan multipara dengan nilai $p=0,017$.

Tabel 4. Uji Korelasi Skor Kecemasan dengan kadar hormon kortisol

\begin{tabular}{ccc}
\hline Variabel & Pearson Corelation & Nilai $\mathbf{p}$ \\
\hline $\begin{array}{c}\text { Skor Kecemasan } \\
\text { Kadar Kortisol }\end{array}$ & 0,610 & $<0,001$ \\
\hline
\end{tabular}

Pearson correlation test

${ }^{*}$ Level significance $<0,05$

Berdasarkan tabel 4. diperoleh hasil ada hubungan signifikan antara skor kecemasan dengan kadar hormon kortisol dengan nilai $p<0,001$. Semakin tinggi skor kecemasan maka kadar hormon kortisol semakin meningkat.

\section{PEMBAHASAN}

Pada penelitian ini, berdasarkan hasil uji statistik menunjukkan bahwa sebagian besar ibu nifas di 24 jam pertama pasca melahirkan mengalami kecemasan sedang $47,4 \%$ dengan rata-rata kadar hormon kortisol $10,034 \mathrm{ng} / \mathrm{ml}$. Hal ini dikarenakan, pada jam-jam pertama kelahiran ibu masih merasakan kelelahan karena proses persalinannya, sehingga ibu masih fokus pada dirinya dan tidak jarang proses menyusui menjadi tertunda. Ini merupakan salah satu faktor yang menghambat produksi ASI sehingga dapat menyebabkan reflek isapan bayi berkurang yang akan menghambat pula pengeluaran hormon oksitosin. Faktor lain yang menghambat pengeluaran oksitosin adalah kecemasan ibu (Rahayu et al., 2018). Kecemasan merupakan perasaan personal dimana terdapat reaksi secara umum atas ketidakmampuan dalam menangani suatu kesulitan ataupun hilangnya rasa aman yang berbentuk ketegangan mental yang membuat gelisah yang ditandai dengan perubahan fisiologis serta psikologis. Rasa cemas merupakan salah satu ketidaknyamanan psikologis yang dialami oleh ibu postpartum.

Penelitian yang dilakukan lben et al, 2013 tentang kejadian Postpartum Depression (PPD) di Nuuk Greenland, memperoleh hasil dari 217 ibu melahirkan terdapat $80,2 \%$ ibu postpartum mengalami depresi postpartum yang dinilai dengan skor EPDS yang terdiri dari 8,6\% ibu postpartum dengan nilai skor 13 poin atau lebih sesuai dengan prevalensi kemungkinan terjadinya PPD, $79 \%$ memperoleh skor $<9$ poin, sedangkan $15 \%$ memperoleh skor $9-12$ poin. Beberapa penelitian telah menunjukkan penurunan prevalensi menyusui pada ibu yang menderita PPD dibandingkan dengan ibu yang tidak mengalami depresi (Motzfeldt et al., 2013).

Sementara itu, menurut Maryam Kianpour, 2019 perbedaan rata-rata skor stres, kecemasan, dan depresi pasca persalinan berbeda antara kelompok intervensi dan kontrol pada waktu 2 minggu, 1 bulan, dan 3 bulan setelah melahirkan. Sehingga 
rata-rata skor stres dan depresi postpartum menurun melalui waktu pada wanita setelah melahirkan. Oleh karena itu, meskipun kecemasan mereka menurun seiring waktu, penurunan ini lebih tinggi dengan aromaterapi lavender, yang mencegah atau mengurangi komplikasi akibat stres, kecemasan, dan depresi pascapartum (Kianpour et al., 2016).

Tingkat kecemasan sering terjadi pada ibu post partum di kerenakan pada kondisi setelah persalinan, kadar estrogen serta progesteron pada tubuh menurun, ibu terkadang merasa kelelahan setelah melahirkan serta merasakan nyeri pada perineum. Ibu dapat merasa sangat tertekan serta dapat menangis untuk hal yang tidak dipahami. Perasaan cemas terhadap kemampuan dirinya dalam hal mengurus dan menjaga bayi setelah pulang dari rumah sakit serta perasaan takut menjadi tidak menarik didepan suami, hal inilah fase adaptasi psikologis yang dialami oleh ibu postpartum. Perubahan secara tiba-tiba pada kondisi hormonal menyebabkan ibu postpartum menjadi lebih sensitif terhadap hal yang dapat ditangani dalam kondisi normal.

Secara umum sebagian besar ibu pasca melahirkan mengalami gangguan emosional atau yang disebut gangguan mood pada ibu postpartum baik primipara maupun multipara (Saleha, 2009; Wahyuningsih, 2018). Sesuai dengan penelitian ini terdapat hubungan signifikan antara usia ibu dan paritas dengan tingkat kecemasan dengan nilai $p<0,05$. Gangguan psikologis seringkali terjadi pada ibu primipara dikarenakan merupakan pengalaman pertama dalam memasuki fase baru menjadi seorang ibu. Tetapi juga tidak jarang terjadi pada ibu multipara. Gangguan ini juga dapat terjadi pada ibu usia 20-35 tahun, walaupun rentang usia tersebut dianggap usia reproduksi sehat, namun sebagian besar pada usia 20-35 tahun termasuk dalam kriteria muda yang rentan mengalami kecemasan sehingga ibu masih kelihatan takut, cemas, serta masih bingung dalam perawatan bayinya nanti.

Tingkat pendidikan seseorang juga akan mempengaruhi pengetahuannya. Pada penelitian ini kecemasan berat $25,9 \%$ terjadi pada ibu dengan pendidikan SD, sedangkan pada ibu dengan pendidikan SMA 47,1 \% mengalami kecemasan sedang dan $47,1 \%$ mengalami kecemasan ringan. Diharapkan dengan pendidikan ibu yang tinggi akan meningkatkan pengetahuan dalam mengatasi kecemasan. Pendidikan tidak hanya formal saja, namun edukasi dapat juga diperoleh dari tenaga kesehatan, kader, kerabat yang sudah mempunyai anak, juga melalui sumber informasi lain seperti buku KIA (Kesehatan Ibu dan Anak), akses sosial media, yang dapat mendukung ibu dalam menjalani perannya sebagai ibu. Meskipun pada tingkat pendidikannya menengah tidak semua kondisi dan kesiapan secara matang, karena pada jenjang ini sebagian besar masih terlihat seperti kematangan psikologis dan banyak hal yang kurang diketahui dalam kondisi setelah kelahiran. Banyak ibu yang tidak tahu bagaimana cara menyusui, mengendong bayi dan merawat bayinya.

Perbedaan tingkat kecemasan pada ibu nifas juga dapat disebabkan oleh mekanisme koping yang dimiliki oleh masing-masing ibu. Semakin bertambahnya usia ibu dan pengalaman kehamilan sebelumnya maupun informasi dari orang lain dapat menambah pengetahuan serta pengalaman baru tentang merawat bayinya sehingga ibu tidak mengalami kecemasan. Sekitar 20\% Kejadian cemas kebanyakan terjadi pada usia berisiko (Siregar et al., 2021). Beberapa penelitian membuktikan peningkatan kadar kortisol menunjukan adanya gejala depresi postpartum (Gaynes et al., 2005). Semakin meningkat respon kortisol dapat mempengaruhi proses pemulihan tubuh ibu (Bhagwagar et al., 2005). Stres psikologi pasca melahirkan mengakibatkan pemulihan tubuh ibu lebih buruk (Field et al., 2013). 
Pada penelitian Soetrisno et al, 2017 menunjukkan adanya peningkatan yang bermakna kadar kortisol dengan kejadian postpartum blues pada persalinan induksi dibanding persalinan normal. Kadar kortisol persalinan induksi meningkatkan risiko kejadian postpartum blues sebesar 5,50 kali dibandingkan kadar kortisol persalinan normal $(O R=5,50$ dan $p=0,028)$. Hal ini dikarenakan stres akan merangsang sumbu Hipothalamus-Pituitary-Adrena (HPA) yang menghasilkan pelepasan kortisol, yang berdampak pada peningkatan postpartum blues (Respati et al., 2017).

Pada penelitian ini ditemukan adanya hubungan signifikan $p<0,001$ antara scor kecemasan dengan kadar hormon kortisol ibu nifas, dimana semakin tinggi skor kecemasan ibu maka kadar hormon kortisol dalam tubuhnya juga semakin tinggi. Menurut Yustinus (2009) tingkat stress sesorang mempengaruhi kerja hormon kortisol yang diatur oleh hipotalamus otak dan kelenjar pituitari. Rasa sakit pasca melahirkan juga merupakan pemicu stress aktivasi sumbu HPA, yang merangsang peningkatan pelepasan kortisol, dan selanjutnya meningkatkan kejadian postpartum blues (Respati et al., 2017). Pada penelitian ini kecemasan berat $20 \%$ terjadi pada usia $30-35$ tahun. Semakin bertambahnya usia ibu, biomarker stress mempengaruhi gejala psikologis ibu (García-Blanco et al., 2017). Stress psikologis mengaktifkan sumbu HPA, menyebabkan peningkatan sekresi hormon kortisol dan epinefrin (Sherwood, 2016). Berdasarkan hasil penelitian lain menunjukkan bahwa fungsi HPA dapat berubah seiring bertambahnya usia. Bukti terbaru menyatakan bahwa usia berkorelasi dengan peningkatan kadar kortisol di urinal dimana kadar kortisol pagi hari pada usia diatas 35 tahun akan menjadi lebih tinggi dari usia yang lebih muda (Gaffey et al., 2016).

\section{SIMPULAN DAN SARAN}

Berdasarkan hasil analisis data dan pembahasan, maka kesimpulan dari penelitian ini secara umum adalah terdapat perbedaan signifikan kadar hormon kortisol ibu nifas primipara dan multipara dengan nilai $p=0,017$ dengan rata-rata kadar hormon kortisol primipara yaitu 14,60 ng/ml lebih tinggi dibandingkan multipara yaitu $7,42 \mathrm{ng} / \mathrm{dl}$. Ada hubungan signifikan antara tingkat kecemasan dengan kadar hormon kortisol dengan nilai $p<0,001$. Nilai kadar hormon kortisol berkaitan dengan skor kecemasan ibu nifas. Semakin tingginya skor kecemasan tinggi maka kadar hormon kortisol juga semakin tinggi. Kecemasan berat lebih banyak terjadi pada ibu primipara dengan usia 30-35 tahun. Pada usia ini, biomarker stress mempengaruhi gejala psikologis ibu. Stress psikologis mengaktifkan sumbu HPA, menyebabkan peningkatan sekresi hormon kortisol dan epinefrin seiring juga bertambahnya usia ibu. Peran dan pendampingan bidan sangat diperlukan untuk membantu ibu nifas dalam memberikan perawatan dan edukasi pasca melahirkan. Penelitian selanjutnya diperlukan upaya-upaya penurunan kecemasan pada ibu nifas.

\section{UCAPAN TERIMA KASIH}

Peneliti menyampaikan terima kasih kepada pihak yang telah berkontribusi dan memberikan dukungan untuk terlaksananya kegiatan penelitian ini, antara lain 1) Direktur Poltekkes Kemenkes Mataram 2) Dinas Kesehatan Kota Semarang, 3) Puskesmas Wilayah Kota Semarang, 4) PMB Bidan Eka Setyowati

\section{DAFTAR PUSTAKA}

Ahmadi, M. R., Hosseini, A., Gheisari, H. R., \& Yavari, M. (2014). Preliminary trial in treatment of postpartum endometritis with intrauterine application of hyperimmune serum in dairy cows. Asian Pacific Journal of Tropical Disease, 4, S360-S365. https://www.sciencedirect.com/science/article/pii/S2222180814604710 
Anggraeni, N. P. D. A., Herawati, L., \& Widyawati, M. N. (2019). The Effectiveness of Postpartum Yoga on Uterine Involution among Postpartum Women $\mathrm{n}$ Indonesia. International Journal of Nursing and Health Services (IJNHS), 2(3), 124-134. https://www.ijnhs.net/index.php/ijnhs/article/download/164/68/1554

Anggraeni, N. P. D. A., Herawati, L., Widyawati, M. N., \& Arizona, I. K. L. T. (2020). The Effect of Exercise on Postpartum Women's Quality of Life: A Systematic Review. Jurnal Ners, 14(3 (si)), 146-154. https://e-journal.unair.ac.id/JNERS/article/view/16950

Bhagwagar, Z., Hafizi, S., \& Cowen, P. J. (2005). Increased salivary cortisol after waking in

Psychopharmacology,

182(1),

54-57.

https://link.springer.com/article/10.1007/s00213-005-0062-z

Fallon, V., Halford, J. C. G., Bennett, K. M., \& Harrold, J. A. (2016). The postpartum specific anxiety scale: development and preliminary validation. Archives of Women's Mental Health, 19(6), 1079-1090. https://pubmed.ncbi.nlm.nih.gov/27571782/

Field, T., Diego, M., Delgado, J., \& Medina, L. (2013). Yoga and social support reduce prenatal depression, anxiety and cortisol. Journal of Bodywork and Movement Therapies, 17(4), 397-403. https://doi.org/https://doi.org/10.1016/j.jbmt.2013.03.010

Gaffey, A. E., Bergeman, C. S., Clark, L. A., \& Wirth, M. M. (2016). Aging and the HPA axis: Stress and resilience in older adults. Neuroscience and Biobehavioral Reviews, 68, 928945. https://doi.org/10.1016/j.neubiorev.2016.05.036

García-Blanco, A., Monferrer, A., Grimaldos, J., Hervás, D., Balanzá-Martínez, V., Diago, V., Vento, M., \& Cháfer-Pericás, C. (2017). A preliminary study to assess the impact of maternal age on stress-related variables in healthy nulliparous women. Psychoneuroendocrinology. https://doi.org/10.1016/j.psyneuen.2017.01.018

Gaynes, B. N., Gavin, N., Meltzer-Brody, S., Lohr, K. N., Swinson, T., Gartlehner, G., Brody, S., \& Miller, W. C. (2005). Perinatal depression: Prevalence, screening accuracy, and screening outcomes: Summary. In $A H R Q$ evidence report summaries. Agency for Healthcare Research and Quality (US). https://www.ncbi.nlm.nih.gov/books/NBK11838/

Kianpour, M., Mansouri, A., Mehrabi, T., \& Asghari, G. (2016). Effect of lavender scent inhalation on prevention of stress, anxiety and depression in the postpartum period. Iranian Journal of Nursing and Midwifery Research, 21(2), 197. https://pubmed.ncbi.nlm.nih.gov/27095995/

Machmudah, M. (2015). Gangguan Psikologis pada lbu Postpartum; Postpartum Blues. Jurnal $\begin{array}{lll}\text { Keperawatan } \quad \text { Maternitas, } & \text { 3(2), }\end{array}$ https://jurnal.unimus.ac.id/index.php/JKMat/article/view/4036

Marmi, S. (2011). Asuhan kebidanan pada masa antenatal. Yogyakarta: Pustaka Pelajar.

Martínez-Galiano, J. M., Hernández-Martínez, A., Rodríguez-Almagro, J., Delgado-Rodríguez, M., \& Gómez-Salgado, J. (2019). Relationship between parity and the problems that appear in the postpartum period. Scientific Reports, 9(1), 1-8. https://www.nature.com/articles/s41598-019-47881-3

Martínez-Galiano, J. M., Hernández-Martínez, A., Rodríguez-Almagro, J., Delgado-Rodríguez, M., Rubio-Alvarez, A., \& Gómez-Salgado, J. (2019). Women's quality of life at 6 weeks postpartum: Influence of the discomfort present in the puerperium. International Journal of Environmental Research and Public Health, 16(2), 1-9. https://doi.org/10.3390/ijerph16020253

Motzfeldt, I., Andreasen, S., Lynge Pedersen, A., \& Lynge Pedersen, M. (2013). Prevalence of postpartum depression in Nuuk, Greenland-a cross-sectional study using Edinburgh Postnatal Depression Scale. International Journal of Circumpolar Health, 72(1), 21114. https://www.ncbi.nlm.nih.gov/pmc/articles/PMC3753142/

Paul, I. M., Downs, D. S., Schaefer, E. W., Beiler, J. S., \& Weisman, C. S. (2013). Postpartum anxiety and maternal-infant health outcomes. Pediatrics, 131(4), e1218-e1224. https://pubmed.ncbi.nlm.nih.gov/23460682/

Rahayu, S., Widyawati, M. N., \& Dewi, R. K. (2018). Pengaruh Masase Endorphin Terhadap Tingkat Kecemasan dan Involusio Uteri lbu Nifas. Jurnal Kebidanan, 8(1), 29-36. http://ejournal.poltekkes-smg.ac.id/ojs/index.php/jurkeb/article/view/3732

Respati, S. H., Sulistyowati, S., \& Kurniawan, H. (2017). The Impacts of Stimulation in 
Protracted Labor to Cortisol Levels and Incidence of Post-Partum Blues. Folia Medica Indonesiana, 53(1), 7-11. https://e-journal.unair.ac.id/FMl/article/view/5483

Ross, L. E., \& McLean, L. M. (2006). Anxiety disorders during pregnancy and the postpartum period: A systematic review. The Journal of Clinical Psychiatry. https://pubmed.ncbi.nlm.nih.gov/16965210/

Saleha, S. (2009). Asuhan kebidanan pada masa nifas. Jakarta: Salemba Medika.

Sherwood, L. (2016). Fisiologi Manusia Dari Sel ke Sistem. (E. by B. U. P. et Al. (ed.); Edisi 8).

Siregar, N. Y., Kias, C. F., Nurfatimah, N., Noya, F., Longgupa, L. W., Entoh, C., \& Ramadhan, K. (2021). Tingkat Kecemasan Ibu Hamil Trimester III dalam Menghadapi Persalinan. Jurnal Bidan Cerdas, 3(1), 18-24. https://doi.org/10.33860/jbc.v3i1.131

Wahyuningsih, H. P. (2018). Asuhan Kebidanan Nifas dan Menyusui. Kementerian Kesehatan Republik Indonesia Pusat Pendidikan Sumber Daya Manusia Kesehatan Badan PPSDMK. http://bppsdmk.kemkes.go.id/pusdiksdmk/wpcontent/uploads/2018/09/Asuhan-Kebidanan-Nifas-dan-Menyusui_SC.pdf

Wenzel, A., \& Stuart, S. C. (2011). Anxiety in childbearing women: Diagnosis and treatment. American Psychological Association. https://psycnet.apa.org/record/2010-13286-000

WHO. (2016). Gender and Women's Mental Health. https://www.who.int/mental_health/resources/gender/en/

Zagoto, S. (2020). Gambaran Pengetahuan Ibu Nifas tentang Adaptasi Psikologis pada Masa Nifas di Klinik Pratama Afiyah Pekanbaru Tahun 2019. Al-Insyirah Midwifery: Jurnal IImu Kebidanan (Journal of Midwifery Sciences), 9(2), 108-113. https://jurnal.stikesalinsyirah.ac.id/index.php/kebidanan/article/view/674 